\title{
EFFECT OF KNOWLEDGE MANAGEMENT AND INTEGRITY ON COMPANY PERFORMANCE THROUGH MOTIVATION AS A MEDIATION VARIABLES IN PT KATELOC INDONESIA
}

\author{
Aga Yudho Prasetyo \\ Student Master of Management \\ Universitas Krisnadwipayana \\ Campus Unkris Jatiwaringin \\ PO BOX 7774/Jat CM Jakarta 13077 \\ Indonesia \\ Abdul Rivai \\ Associate Professor \\ Universitas Krisnadwipayana \\ Campus Unkris Jatiwaringin \\ PO BOX 7774/Jat CM Jakarta 13077 \\ Indonesia \\ Suharto \\ Associate Professor \\ Universitas Krisnadwipayana \\ Campus Unkris Jatiwaringin \\ PO BOX 7774/Jat CM Jakarta 13077 \\ Indonesia
}

Vol: 1, Issue: 1

September/2020

https://ijbssrnet.com/index.php/ijbssr

DOI: 10.47742/ijbssr.v1n1p1

\begin{tabular}{l}
\hline A R T I C L E I N F O \\
Article history: Article \\
Received \\
Revised \\
Accepted: September, 2020 \\
DOI: $10.47742 /$ ijbssr.v1n1p1
\end{tabular}

\begin{abstract}
A B S T R A C T
This study aims to examine the effect of knowledge management and integrity on company performance through motivation as a mediating variable at PT. Kateloc Indonesia. The research sample was 283 employees. The data collection technique used questionnaires and data analysis used path analysis. The results showed that the knowledge management variable partially affected company performance. The integrity variable partially affects company performance. The motivation variable partially affects company performance. Knowledge management variables partially influence motivation. The integrity variable partially affects motivation.

The influence of knowledge management on company performance is 0.548 . The effect of knowledge management on performance through motivation is $0.676 \mathrm{X} 0.868=0.587$. In this case, the indirect effect is greater than the direct effect, so it can be said that the motivation variable is intervening. The direct effect of integrity on company performance is 0.659. Meanwhile, the influence of integrity on company performance through motivation is $0.782 \times 0.868=0.679$. In this case, the indirect effect is greater than the direct effect, so it can be said that the work motivation variable is intervening.
\end{abstract}

Keywords : knowledge management, integrity, motivation and company performance

\section{Introduction}

Company performance should be measured not only in terms of financial concepts but also from non-financial terms. Performance can be measured from productivity, quality, consistency, and so on. On the other hand, company performance measures results, behavior, and normative, education, and the resulting concepts, including management development (Richard, 2010).

Noe, et al (2003) explained that to obtain maximum company performance, a company needs employees who have maximum individual job performance as well. $\mathrm{HR}$ has a dominant role in processing resources and materials so that they become products through their policies. Therefore, to improve performance, it is necessary to get sufficient attention so that HR can work efficiently and produce a performance that can contribute to company productivity. To get optimal performance, there have been many studies that have attempted to identify various factors that affect individual performance and company performance, such as Brahmasari, and Suprayetno, 2008; Murty, Hudiwinarsih (2012); Soedjono (2005); Biantoro (2002).

According to Richard et al (2010) company performance is something that is produced by a company that includes outcomes, namely financial performance such as profit as 
https://ijbssrnet.com/index.php/ijbssr

DOI: $10.47742 /$ ijbssr.v1n1p1

measured by return on assets, return on investment, and so on, market performance, such as expanding market share, and sales. Also, the return from the shareowner is the return of the shareowner and the economic increase of the shareowner. In some areas, company performance can also be measured from other things such as strategic plans, operations, finance, legal, and company development. Developing an institution or company is a must to survive in the world's competitive climate.

Company performance is influenced by various factors, namely knowledge management, integrity, and motivation. Knowledge management is a series of activities used by companies or companies to identify, create, explain, and distribute knowledge to be reused, known, and studied within the company. These activities are usually related to company objectives and are aimed at achieving a certain outcome such as shared knowledge, increased performance, competitive advantage, or a higher level of innovation.

The concept of knowledge management includes the management of human resources (HR) and information technology (IT) to achieve better companies so that they can win a business competition. The development of information technology plays an important role in the concept of knowledge management. Almost all activities in human life will be colored by mastery of information technology so that when talking about knowledge management, it cannot be separated from management.

This development shows the acceleration of changes in all areas of life, due to the effects of globalization and the very accelerated development of information technology. This condition has resulted in the need for new ways of responding to everything that happens to survive. Emphasis on the increasing importance of the quality of human resources (HR) is one response in addressing these changes, and this of course requires efforts to improve and develop HR.

Another factor to consider in improving company performance is integrity. Integrity is consistency and unshakable persistence in upholding noble values and beliefs. Another definition of integrity is a concept that points to consistency between actions with values and principles. In ethics, integrity is defined as the honesty and truth of one's actions. The opposite of integrity is hypocrisy (hypocritical). A person is said to have "integrity" if his actions are following the values, beliefs, and principles he holds (Wikipedia). Simply put, the characteristic of a person with integrity is marked by only words and deeds, not someone whose words cannot be grasped. A person who has integrity is not a human type with many faces and appearances that are tailored to his motives and personal interests. Integrity is a key character for a leader. A leader who has integrity will get the trust of his employees. Leaders with integrity are trusted because what they say becomes their actions.

The definition of integrity is a way of thinking, saying, behaving, and acting properly and correctly and upholding the code of ethics and moral principles. Motivation also has an impact on company performance. Motivation is an impulse that causes a person to do an action to achieve a certain goal. Motivation comes from the word motive which means "impulse" or stimulation or "driving force" that is in a person. According to Weiner Elliot et al. (2000), motivation is defined as an internal condition that arouses us to act, encourages us to achieve certain goals, and keeps us interested in certain activities.

According to Uno (2009), motivation can be interpreted as internal and external encouragement within a person as indicated by their existence; passions and interests; urges and needs; hopes and ideals; appreciation, and respect. Motivation is something that makes someone act (Howard, 1999) states that motivation is the impact of a person's interaction with the situation he is facing (Siagian, 2008). Motivation becomes a force, energy or power, or a complex situation and readiness in the individual to move towards a certain goal, whether consciously or not (Makmun, 2003).

\section{Literature Review}

\section{Knowledge Management}

Knowledge management is a process to regulate something that is done by a group of people or companies to achieve the company's goals by working together to utilize the resources they have. Etymologically, the word management is taken from ancient French, namely management, which means the art of organizing and implementing. Management can also be defined as an effort to plan, coordinate, manage, and control resources to achieve goals efficiently and effectively. Effective, in this case, is to achieve goals according to planning and efficient to carry out work correctly and organized.

According to Handoko (2004), there are three main reasons why management is needed:

- Management is necessary so that personal and company goals can be achieved

- Next, management is also required to maintain a balance between conflicting goals, objectives, and activities of the parties that have an interest in the company.

- Management is needed to achieve efficiency and effectiveness of a company's work

A growing company needs management in several ways; includes strategic management, human resource management, production, marketing, and other management.

\section{Integrity}

Integrity is consistency and unshakable determination in upholding noble values and beliefs. Another definition of integrity is a concept that denotes consistency between actions with values and principles. In ethics, integrity is defined as the honesty and truth of one's actions. The opposite of integrity is hypocrisy (hypocritical). A person is said to have "integrity" if his actions are following the values, beliefs, and principles he holds (Wikipedia). Simply put, the characteristic of a person with integrity is marked by only words and deeds, not someone whose words cannot be grasped. A person who has integrity is not a 
human type with many faces and appearances that are tailored to his motives and personal interests. Integrity is a key character for a leader. A leader who has integrity will earn the trust of his employees. Leaders with integrity are trusted because what they say becomes their actions. The definition of integrity is a way of thinking, saying, behaving, and acting properly and correctly and upholding the code of ethics and moral principles. In the Big Indonesian Dictionary, the meaning of integrity is (1) quality, character, or condition that shows a complete unity so that it has the potential and ability to radiate authority; (2) honesty.

\section{Motivation}

Motivation is an impulse that causes a person to do an action to achieve a certain goal. Motivation comes from the word motive which means "impulse" or stimulation or "driving force" that is in a person. According to Elliot et al. (2000), motivation is defined as an internal condition that arouses us to act, encourages us to achieve certain goals, and keeps us interested in certain activities.

According to Uno (2007), motivation can be interpreted as internal and external encouragement within a person as indicated by their existence; passions and interests; urges and needs; hopes and ideals; appreciation, and respect. Motivation is something that makes someone act (Howard, 1999) states that motivation is the impact of a person's interaction with the situation he is facing (Siagian, 2004).

Motivation becomes a force, energy or power, or a complex situation and readiness in the individual to move towards a certain goal, whether consciously or not (Makmun, 2003).

A person's motivation can be generated and grow through himself-intrinsic and extrinsic-environment (Elliot et al., 2000; Howard, 1999). Intrinsic motivation means the desire of oneself to act without external stimulation (Elliott, 2000). Intrinsic motivation will be more profitable and provide consistency in learning. Extrinsic motivation is defined as motivation that comes from outside the individual and cannot be controlled by the individual (Howard, 1999). Elliott et al. (2000), exemplified the values, gifts, and / or rewards that are used to stimulate a person's motivation.

For example, in learning activities, motivation is the driving force that ensures the continuity of learning activities and provides direction for learning activities so that the desired goals can be met. Thus motivation is very influential on one's learning outcomes. If someone does not have the motivation to learn, that person will not achieve optimal learning outcomes. To be able to learn well, it requires good process and motivation, providing motivation to learners, meaning moving someone so that he wants or wants to do something. motivation can be viewed as a function, meaning that motivation functions as a driving force from within an individual to carry out certain activities in achieving goals.

Motivation is seen in terms of process, meaning that motivation can be stimulated by external factors, to generate motivation in students who go through the stimulation process of learning so that they can achieve the desired goals. Motivation is viewed in terms of goals, meaning that motivation is the stimulus target to be achieved. If a person has the desire to learn something, then he will be motivated to achieve it.

\section{Company Performance}

The definition of company performance refers to the ability of employees to carry out all the tasks that are their responsibility. These tasks are usually based on indicators of success that have been implemented. As a result, it will be known that an employee belongs to a certain level of work. The level can be various terms. Performance can be categorized as over target, on target, or under target. Departing from the things referred to as a whole for the work of an employee. The definition of company performance is a description of the level of achievement of the implementation of an activity program or policy in realizing the goals, objectives, vision, and mission of the company as outlined in the strategic planning of a company (Moeheriono, 2010: 60). Mangkuprawira (2011: 218-219) says that performance is a matter, or the overall success rate of a person during a certain period in carrying out a task compared to various possibilities, such as work standards, targets, or targets or criteria that have been determined in advance and have been agreed together.

According to Wibowo (2016: 19), performance is a management style in managing performance-oriented resources that carries out an open and sustainable communication process by creating a shared vision and a strategic and integrated approach as a driving force to achieve company goals. According to Rivai and Sagala (2009: 548) suggest that: "Performance is a function of motivation and ability to complete a task or someone's job should have a certain degree of willingness and level of ability. According to Richard et al (2009) company performance is something that is produced by a company that includes outcomes, namely financial performance such as profit as measured by return on assets, return on investment, and so on, market performance such as market share expansion., and sales. Besides, the return from the shareowner is the return of the shareowner and the economic increase of the shareowner.

In some areas, company performance can also be measured from other things such as strategic plans, operations, finance, legal, and company development. Developing an institution or company is a must to survive in the world's competitive climate.

Companies proposed by experts, including Miner (2005), suggest that four dimensions can be used as benchmarks or indicators in assessing company performance, namely:

a. Quality, namely: the level of error, damage, accuracy.

b. Quantity, namely: the number of jobs produced.

c. The use of time at work, namely: absenteeism, tardiness, effective working time / lost work hours.

d. Cooperation with other people at work.

\section{Research Methods}

Time and Location of Research 
The research will be conducted in October-December 2019 by taking the location at PT. Kateloc Indonesia.

Research Design

This study uses an explanatory analysis approach. This means that every variable presented in the hypothesis will be
Vol: 1, Issue: 1

September/2020

https://ijbssrnet.com/index.php/ijbssr

DOI: 10.47742/ijbssr.v1n1p1

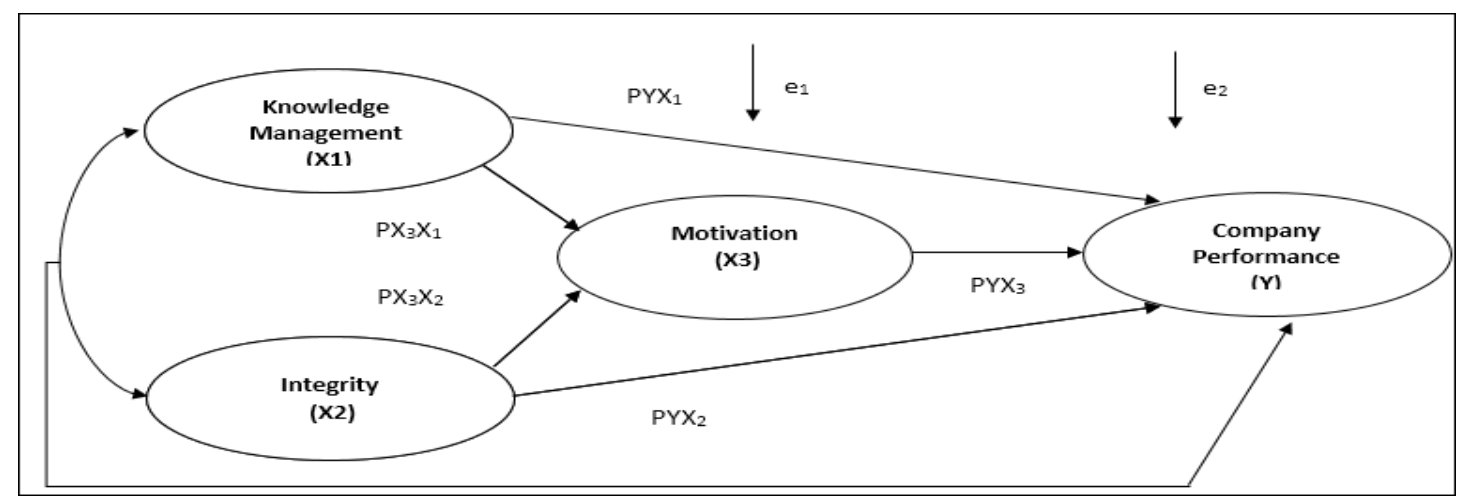

Figure 1. Overall Path Analysis

\section{Population and sample}

The population in this research are employees who work at the PT. Kateloc Indonesia. While the sample used includes 283 employees who work in company offices. This sample was taken using the random sampling method with the Slovin formula, namely $=962 /(1+0.052 \times 962)=283$.

\section{Research Instruments}

The research instrument uses a questionnaire which will be arranged based on predetermined dimensions.

\section{Data Source}

To obtain concrete and objective data, research must be conducted on the problem under study, while the steps that the researcher takes in data collection are:

Primary data is data obtained directly from the object of research. In this case, primary data is obtained from field research, namely the data collection method which is carried out by direct research on the object of research in question.

Secondary data is data obtained indirectly from the object of research. In this case, secondary data is obtained from the research library, namely the method of collecting data by studying and understanding literary books created by authors who can be justified in their theoretical basis.

\section{Data Analysis Technique}

The stages of data processing in this research are classical assumption test with regression such as linearity test, heteroscedasticity test, normality test, multicollinearity and autocorrelation test as well as search for descriptive statistics, namely the average value, the median mode, the standard deviation and the range.

\section{Research Results and Discussion}

\section{The influence of knowledge management on} company performance

The results of the analysis of the influence of knowledge management on company performance show that the coefficient of knowledge management is 0.548 . The $t$ value is 10.968 . The observed through testing the causal relationship of the independent variable to the dependent variable. The relationship between variables can be described in the form of a path analysis diagram as follows: The research conceptual framework can be explained as follows: significant value is 0.00 . This significant value is smaller than 0.05 . This means that knowledge management variables partially affect company performance. The magnitude of the influence of knowledge management on company performance is known that the value of $r$ squared is 0.3 . This means that the influence of knowledge management variables on performance is $30.0 \%$ and the rest is influenced by other variables that are not included in the equation model.

\section{The effect of integrity on company performance}

The results of the analysis of the effect of integrity on the performance show that the coefficient of integrity is 0.659 . The $t$ value is 14,705 . The significant value is 0.00 . This significant value is smaller than 0.05 . This means that the integrity variable partially affects company performance. The magnitude of the effect of integrity on company performance is known to be the value of $r$ squared of 0.435 . This means that the influence of the Integrity variable on company performance is $43.5 \%$ and the rest is influenced by other variables that are not included in the equation model.

\section{The influence of motivation on company} performance

The results of the analysis of the effect of work motivation on company performance show that the motivation coefficient is 0.868 . The t value is 29.256 . The significant value is 0.00 . This significant value is smaller than 0.05 . This means that the motivation variable partially affects company performance. The magnitude of the influence of motivation on company performance is known to be the value of $r$ squared of 0.753 . This means that the influence of the motivation variable on company performance is $75.3 \%$ and the rest is influenced by other variables that are not included in the equation model.

\section{The influence of knowledge management on}

\section{motivation}

The results of the analysis of the influence of knowledge management on motivation show that the coefficient of 
knowledge management is 0.676 . The $t$ value is 15.388 . The significant value is 0.00 . This significant value is smaller than 0.05 . This means that the knowledge management variable partially affects motivation. The magnitude of the influence of knowledge management on motivation is known to be the value of $r$ squared of 0.457 . This means that the influence of the motivation variable on company performance is $45.7 \%$ and the rest is influenced by other variables that are not included in the equation model.

\section{The effect of integrity on motivation}

The results of the analysis of the effect of integrity on motivation show that the coefficient of integrity is 0.782 . The $t$
Vol: 1, Issue: 1

September $/ 2020$

https://ijbssrnet.com/index.php/ijbssr DOI: $10.47742 /$ ijbssr.v1n1p1

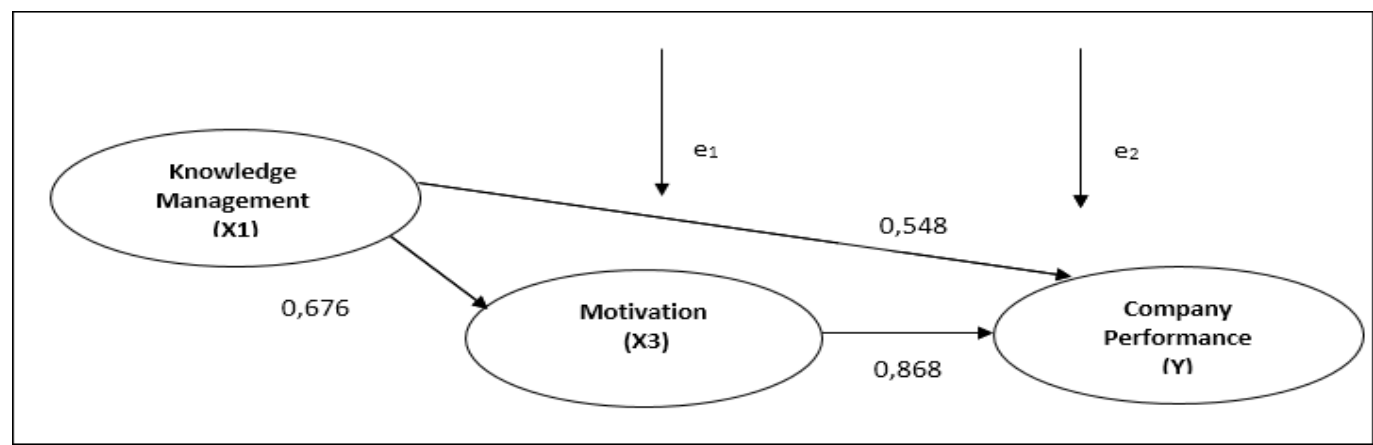

Figure 2. Path analysis of the influence of X1 on Y through X3

Based on the figure above, it can be seen that the influence of knowledge management on company performance is 0.548 . The effect of knowledge management on performance through motivation is $0.676 \mathrm{X} 0.868=0.587$. In this case, the indirect effect is greater than the direct effect, so it can be said that the work motivation variable is intervening. value is 21.046. The significant value is 0.00 . This significant value is smaller than 0.05 . This means that the variable integrity partially affects motivation. The magnitude of the influence of integrity on motivation is known to be the value of $r$ squared of 0.612 . This means that the effect of the integrated variable on motivation is $61.2 \%$ and the rest is influenced by other variables that are not included in the equation model.

6. The influence of knowledge management on company performance through motivation variables

Based on the partial path analysis above, it can be described as follows. The analysis is an analysis on a path with a substructure image as follows.

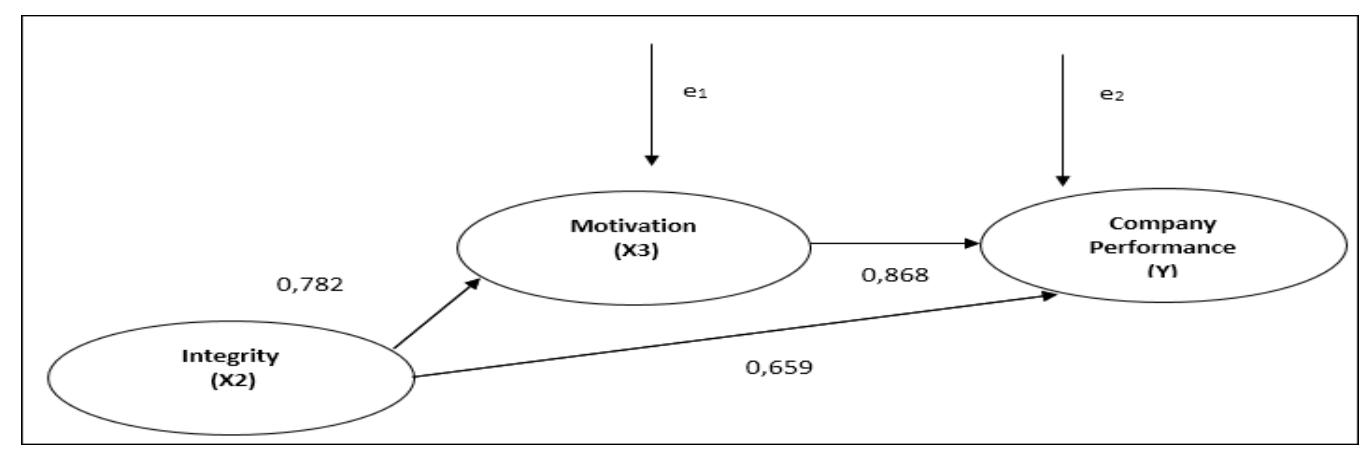

Figure 3. Path analysis of the influence of $X 2$ on $Y$ through $X 3$

Based on the picture above, it can be seen that the direct effect of integrity on company performance is 0.659 . While the effect of integrity on company performance through motivation variables is $0.782 \times 0.868=0.679$. In this case, the indirect effect is greater than the direct effect, so it can be said that the motivation variable is intervening.

Conclusions and Recommendations

Conclusion
Knowledge management variables partially influence company performance. The value of $r$ squared is 0.3 . This means that the influence of knowledge management variables on company performance is $30.0 \%$ and the rest is influenced by other variables that are not included in the equation model.

The integrity variable partially affects company performance. The value of $r$ squared is 0.435 . This means that the influence of the integrity variable on company performance is 
https://ijbssrnet.com/index.php/ijbssr

DOI: $=10.47742 /$ ijbssr.v1n1p1

http://iarpnet.org/

$43.5 \%$ and the rest is influenced by other variables that are not included in the equation model.

The motivation variable partially affects company performance. The value of $r$ squared is 0.753 . This means that the influence of the motivation variable on company performance is $75.3 \%$ and the rest is influenced by other variables that are not included in the equation model.

Knowledge management variables partially influence motivation. The value of $r$ squared is 0.457 . This means that the influence of the motivation variable on company performance is $45.7 \%$ and the rest is influenced by other variables that are not included in the equation model.

The integrity variable partially affects motivation. The value of $r$ squared is 0.612 . This means that the influence of the integrity variable on motivation is $61.2 \%$ and the rest is influenced by other variables that are not included in the equation model.

The influence of knowledge management on company performance is 0.548 . The effect of knowledge management on performance through motivation is $0.676 \times 0.868=0.587$. In this case, the indirect effect is greater than the direct effect, so it can be said that the motivation variable is intervening.

\section{References}

Brahmasari, Ida Ayu dan Agus Suprayetno, (2008). Pengaruh Motivasi Kerja, Kepemimpinan dan Budaya Organisasi Terhadap Kepuasan Kerja Karyawan serta Dampaknya pada Kinerja Perusahaan (Studi kasus pada PT. Pei Hai International Wiratama Indonesia). Jurnal Manajemen dan Kewirausahaan. Vol 10 No. 2, September : 124-135. http://jurnalmanajemen.petra.ac.id/index.php/man/article/view/17039.

Daft, Richard L. (2010). Manajemen. Edisi Kelima Jilid Satu. Jakarta : Erlangga.

Elliot, et.al, (2000). Educational Psychology: Effective Teaching, Effective Learning, The Mc. Graw Hill Companies, America.

Howard, D.L and Pritchard, M. P.; Havitz, M. C. (1999), “Analyzing The Commitment Loyalty Link in Service Context," Journal the Academy of Marketing Science, Vol. 27, No. 3, pp. 333-348

Makmun, Abin Syamsuddin. (2003). Psikologi Pendidikan. Bandung: Rosda Karya Remaja.

Mangkuprawira, S.Tb., (2011), Manajemen Sumber Daya Manusia Strategik, Ghalia Indonesia, Bogor.

Miner, John. B. (2005). Organizational Behavior: Performance and Productivity, First Edition, random House, Inc. New York.

Moeheriono. (2010). Pengukuran Kinerja Berbasis Kompetensi. Surabaya: Ghalia Indonesia.

Murti dan Hudiwinarsih. (2012). Pengaruh Kompensasi, Motivasi Dan Komitmen Organisasional Terhadap Kinerja Karyawan Bagian Akuntansi (Studi Kasus Pada Perusahaan Manufaktur di Surabaya). The Indonesian Accounting Review Volume 2, No. 2, July 2012, pages 215 - 228. https://journal.perbanas.ac.id/index.php/tiar/article/view/97

Noe, Raymond A, et al., (2003), Human Resources Management: Gaining a Competitive Advantage, 4 edition, McGraw-Hill/Irwin, New York.

Rivai, Veithzal dan Sagala, Ella Jauvani. (2009). Manajemen Sumber Daya Manusia untuk Perusahaan dari Teori ke Praktik. Jakarta: PT Raja Grafindo.

Siagian, Sondang P. (2008). Manajemen Sumber Daya Manusia. PT. Bumi Aksara. Jakarta.

T. Hani Handoko. 2004. Manajemen Personalia dan Sumberdaya Manusia, Penerbit BPFE, Yogyakarta Uno, Hamzah B. 2009. Teori Motivasi Dan Pengukurannya (Analisis Di Bidang Pendidikan). Bumi Aksara. Jakarta. Wibowo. (2016). Manajemen Kinerja. Jakarta: PT Rajagrafindo Persada. 